\title{
Improving Self esteem and Games Performances through Games based Learning in Physical Education Content Basketball at Secondary High School
}

\author{
Ahmad Hamidi* \\ Dept. Health and Recreation Education, Faculty of Sport \\ and Health Education \\ Universitas Pendidikan Indonesia \\ Bandung, Indonesia \\ *ahmadhamidi@upi.edu
}

\author{
Sofyan Achmad Hanif, Mochamad Asmawi \\ Dept. Sport Education, Faculty of Sport Science \\ State of Jakarta University \\ Jakarta, Indonesia
}

\begin{abstract}
The purpose of this study is to examine and analyze the effect of games-based learning in physical education of Basketball game on junior high school students' self esteem and skill play in class VII. This study uses quasi experiment with pretest-posttest without control group design which implemented for 1.5 months with 16 meetings, thrice a week. The total numbers of sample are 30 students (15 females and 15 male) aged between 13-14 years old in Bandung, West Java Indonesia. A measuring instrument used for measuring students' self esteem called Self esteem inventory (SEI) created by Coopersmith and modified by researchers; this questionnaire is a closed-ended questionnaire. Each student was given a pretest and posttest consisting of 40 items that they must respond. Meanwhile, to measure students' game performances this study uses GPAI test (games performance analysis instrument). After implementing the learning program, it is found that the game-based approach gives a significant effect on the improvement of students' self esteem and basketball playing skills. For self esteem, the average score of male students on pretest is 2.05 and 2.21 on posttest; the average score for female students is 1.98 on pretest and 2.04 on the posttest. For game performances, the average score of male students on pretest is 1.75 and 2.77 on posttest whereas the average score for female students is $\mathbf{1 . 5 7}$ on pretest and 2.34 on posttest.
\end{abstract}

Keywords—self esteem; games performance; games based learning; basketball

\section{INTRODUCTION}

Self esteem is often used to indicate how a person evaluates himself. Individual evaluations and self-reflect primarily about acceptance or rejection, and an indication of individual confidence in their abilities, meanings, successes, and rewards [1]. In brief, this self esteem is usually called "self judgement" about the feelings and the meanings that are expressed in the individual's attitude toward himself. This means that someone who has a high self-esteem tend to be more confident in life than those who have low self-esteem.

The results show that self-esteem effects the attitude of a person to his status as an adolescent [2]. Adolecents who have a positive self-esteem, they will not be influenced by the environment and they can express and take what they really want to do and will eventually avoid negative behaviors [3]. During childhood and adolescence, self-concept and selfesteem begin to develop [4]. Therefore, it is important for adolescents to develop self-concept and high positive selfesteem.

Hence, there is no doubt that self-esteem is important for the development of academic, social, and emotional aspects [5]. The development of these skills is important for adolescents as part of their overall learning to be a better person; especially in facing this globalization era that sometimes creates a personal imbalance. This means that learning to improve self-esteem for adolescents should be given in a systematic and directed way and in an educational frame based on each individual needs.

Self-esteem is very important for the success of adolescents inside or outside the classroom environment. This is because that self-esteem is the basis skill for adolescent to have in social interaction with people and the environment. One of the scientific disciplines that is capable in developing student's self-esteem is through physical education. The role of physical education in schools is to provide opportunities for students to be directly involved in various learning experiences through systematic physical activity, playing and sports [6].

Physical education learning process requires students to be physically and psychologically active, also learning by utilizing physical activity becomes a challenge for teachers in teaching it [6]. On the other hand, the challenge in learning physical education is also perceived by students; the learning seems not that attractive for learners. Learners assume that it is merely a physical lesson; i.e., only to practice various motion without any meaning from them. The results of field observations indicate that the participation rate of both male and female students in learning physical education tend to be very low, resulting low ability of students' skills and movement skills.

To solve the problem, it is necessary to find out how to provide a physical lesson that will enhance self-esteem, and improve skills in sports. A good learning has to give 
opportunity for students to learn independently and according to what they want.

One of the innovative learning that is relevant to the involvement of the students' active role in developing game performances is a student-centered learning approach which is a game-based approach. In this approach, students will feel the joy and pleasure in doing physical learning, because the students themselves who explore the contents of physical activity in the form of games based on their needs. Consequently, this game-based approach is expected to more motivated students in learning physical education comprehensively.

On the other hand, this game-based approach is also more focused on social interaction with others. This is very important in order to synchronize the whole physical education as individual, and social learning [7]. The approach is also expected to be an alternative way to overcome the problems of students' low self-esteem and playing basketball skill. Thus, this study will give its own color in providing comprehensive benefits for students and teachers in terms of cognitive, affective, psychomotor, and social.

Certainly, physical education cannot only help to develop students' psychomotor skills, but also can provide psychological benefits through the development of personal responsibility. However, the self-development of students is not the result of participation in physical activity. The use of appropriate strategies and learning models will determine the teaching and learning activities, one of them is to improve students' self-esteem and game performances.

The results show that the proper selection of learning models by teachers will be able to make students more conducive because students are more participating, and more sensitive in teaching and learning activities [8]. Other studies show that there are two keys that influence the perspective on the effectiveness of learning strategies, namely the affective aspect and belief in their own knowledge [9]. One of the learning models that is expected can improve self-esteem is games based learning model.

This games-based learning model places tactical and strategic problems in a modified learning environment situation [10]. This teaching approach utilizes active learning effectively in which students will ultimately be able to evaluate and take decisions against themselves and the problems they face. The focus of this learning model is the involvement of students in games where students are required to have motor and cognitive skills. This means students are required to solve the problem by themselves especially personal problems such as self-esteem and motor. By using this approach, it is expected to improve students' sell-esteem and game performances.

\section{METHODS}

\section{A. Objectives}

The purpose of this study is to examine the effect of the implementation of physical education in basketball game toward students' self-esteem and game performances of class VII junior high school which given approximately 1.5 months or 16 meeting, thrice a week. Additionally, this study was taken to see the different skills of male and female students in playing basketball associated with cognitive aspects such as how students make the right decisions, and perform effective moves in basketball.

\section{B. Design and Context}

Participants in this study are 30 students (15 male and female respectively) from grade VII (Seven) SMP Lab School UPI aged 13-14 years old. This study used quasi experimental descriptive pretest-posttest design without control group. Group characteristics are quite homogeneous.

\section{Program and Procedure}

The procedure undertaken in this study is designing didactic units to improve self-esteem and game performances through basketball games. After designing the objectives, contents and evaluation sessions will be carried out for 1.5 months and should examine the resulting effect.

The implementation program for the development of SMP Lab School students' self-esteem and game performances is based on the game plan that the researcher has made and has been validated by a physical education specialist. The contents of self-esteem and these skills are incorporated into the game of the Training Unit basketball. The content of the lesson includes activities: a) Self-respect, b) cooperation, c) asking questions, d) following instructions, e) joining a group, and f) waiting for a turn. Interventions in this study used various techniques such as case studies, small group discussions and brainstorming, solving methods of students' technical and tactical problems, finding personal value methods, inculcating values and clarifying value methodologies, critical understanding and role-playing.

\section{Tools}

To measure self-esteem, this study used a questionnaire called Self Esteem Inventory (SEI) created by Coopersmith [1], which is a closed-ended questionnaire. Each student is given a pretest and posttest consisting of 40 items that they have to respond; the measurement scale used in the self-esteem questionnaire refers to the Guttman scale with the number "1" for a positive answer, and the number " 0 " for a negative answer. Meanwhile, for measuring the game performances, the instruments called as Games Performance assessment instrument (GPAI) created by Oslin, et al. [11]. The instrument is done by observing through format simple event recording (tally). Each student is given pretest and posttest with this GPAI Instrument. The aspects of GPAI measured include: 1) involvement in the game, 2) standard decision making, 3) skill standards, 4) standard of providing support, and 5) play performance.

To measure self-esteem, this study used a questionnaire called Self Esteem Inventory (SEI) created by Coopersmith [1], which is a closed-ended questionnaire. Each student is given a pretest and posttest consisting of 40 items that they have to respond; the measurement scale used in the self-esteem questionnaire refers to the Guttman scale with the number "1" for a positive answer, and the number " 0 " for a negative 
answer. Meanwhile, for measuring the game performances, the instruments called as Games Performance assessment instrument (GPAI) created by Oslin, et al. [11]. The instrument is done by observing through format simple event recording (tally). Each student is given pretest and posttest with this GPAI Instrument. The aspects of GPAI measured include: 1) involvement in the game, 2) standard decision making, 3) skill standards, 4) standard of providing support, and 5) play performance.

\section{RESULTS}

TABLE I. DESCRIPTIVE STATISTICS

\begin{tabular}{|c|c|c|c|c|c|c|c|c|c|c|}
\hline \multirow{3}{*}{ Gander } & \multicolumn{4}{|c|}{ Self Esteem } & \multicolumn{4}{|c|}{ Skill Play } & \multicolumn{2}{|c|}{$\begin{array}{c}\text { Preliminary } \\
\text { Knowledge }\end{array}$} \\
\hline & \multicolumn{2}{|c|}{ Pre Test } & \multicolumn{2}{|c|}{ Post Test } & \multicolumn{3}{|c|}{ Pre Test } & \multirow{2}{*}{\begin{tabular}{|c|}
$\begin{array}{c}\text { Post } \\
\text { Test }\end{array}$ \\
SD
\end{tabular}} & & \\
\hline & $M$ & $D$ & $M$ & $D$ & $M$ & $S D$ & $M$ & & $M$ & $D$ \\
\hline $\begin{array}{l}\text { Male } \\
(\mathrm{Pa})\end{array}$ & 82.2 & 4.1 & 84.0 & 4.1 & 1.7 & 0.5 & 2.8 & 0.7 & 87.3 & 4.5 \\
\hline $\begin{array}{l}\text { Female } \\
(\mathrm{Pi})\end{array}$ & 79.1 & 3.4 & 81.4 & 3.3 & 1.4 & 0.4 & 2.3 & 0.6 & 80.2 & 3.8 \\
\hline All & 80.6 & 4.0 & 82.7 & 3.9 & 1.6 & 0.5 & 2.6 & 0.7 & 83.8 & 5.5 \\
\hline
\end{tabular}

${ }^{\mathrm{a}} \cdot \mathrm{M}=$ Average, $\mathrm{SD}=$ Standard Deviation

TABLE II. OVERALL RESULTS OF PAIRED SAMPLE T TEST THE INFLUENCE OF GAME-BASED APPROACH ON SELF-ESTEEM AND GAMES PERFORMANCES

\begin{tabular}{|c|c|c|c|c|c|c|}
\hline \multirow{2}{*}{ Pair } & \multicolumn{3}{|c|}{ Paired Differences } & \multirow{2}{*}{$\mathbf{T}$} & \multirow{2}{*}{ df } & \multirow{2}{*}{$\begin{array}{l}\text { Sig. (2- } \\
\text { tailed) }\end{array}$} \\
\hline & Mean & $S D$ & SEM & & & \\
\hline $\begin{array}{l}\text { Pre-Post Self } \\
\text { Esteem }\end{array}$ & -2.10 & 1.64 & 0.30 & - & 29.00 & 0.00 \\
\hline $\begin{array}{l}\text { Pre-Post Skill } \\
\text { Play }\end{array}$ & -1.01 & 0.82 & 0.15 & $\begin{array}{l}- \\
6.78\end{array}$ & 29.00 & 0.00 \\
\hline
\end{tabular}

Based on the analysis results in Table 2 , it is obtained that the value $t=-7.04$ with p_value $=0.00(0.00<0.05)$, this proves that there is a significant increase before and after the implementation of game-based approach to self-esteem, this also means game-based approach has a significant effect on the improvement of self-esteem. Likewise, in game performances variable, the analysis results show that the value of $t=-6.78$ with p_value $=0.00(0.00<0.05)$, this proves that there is a significant increase before and after implementing the approach to students' game performances, this also proves that the game-based approach gives a significant effect on the improvement of basketball playing skills. In accordance to the results of the analysis, it can be concluded that the game-based approach has a significant effect on improving self-esteem and game performances.
TABLE III. RESULTS OF INDEPENDENT SAMPLE T TEST THE INFLUENCE OF GAME-BASED APPROACH ON SELF-ESTEEM AND GAMES PERFORMANCES BASED ON GENDER

\begin{tabular}{|l|c|c|c|c|c|c|c|c|}
\hline \multicolumn{2}{|l|}{} & \multicolumn{2}{|c|}{$\begin{array}{c}\text { Levene's } \\
\text { Test for } \\
\text { Equality of } \\
\text { Variances }\end{array}$} & \multicolumn{5}{|c|}{ t-test for Equality of Means } \\
\hline & $\boldsymbol{F}$ & Sig. & $\boldsymbol{T}$ & $\boldsymbol{d f}$ & $\begin{array}{c}\text { Sig. (2- } \\
\text { tailed) }\end{array}$ & $\begin{array}{c}\text { Mean } \\
\text { Difference }\end{array}$ & $\begin{array}{c}\text { Std. Error } \\
\text { Difference }\end{array}$ \\
\hline $\begin{array}{c}\text { Self } \\
\text { Esteem }\end{array}$ & $\begin{array}{c}\text { Equal } \\
\text { variances } \\
\text { assumed }\end{array}$ & 1.716 & .201 & -.855 & 28 & $\mathbf{. 4 0 0}$ & -.513 & .600 \\
\hline $\begin{array}{c}\text { Skill } \\
\text { Play }\end{array} \begin{array}{c}\text { Equal } \\
\text { variances } \\
\text { assumed }\end{array}$ & .056 & .814 & 152 & 28 & $\mathbf{. 8 8 0}$ & .046 & .306 \\
\hline
\end{tabular}

The result depicted on Table 3 shows the comparison test of self-esteem and basketball playing skills improvement based on gender. The results show that in self-esteem variable, the value of $\mathrm{t}=-0.885$ and $\mathrm{p}$ _value $=0,400(0,400>0,00)$ which indicate that after implementing the approarch there is no significant difference about improvement of self-esteem between male and female students. This means that after implementing game-based approach, both of male and female students improve equally in terms of self-esteem. Then, the score of playing basketball skill varible is $\mathrm{t}=0.152$ and p_value $=0,880(0,880>0,00)$, this means that there is no significant difference between male and female students on the improvement of basketball skill after implementing gamebased approach. This also means that male and female students improve almost equal in terms of playing basketball skill.

TABLE IV. RESULTS OF INDEPENDENT SAMPLE T TEST THE INFLUENCE OF GAME-BASED APPROACH TO SELF-ESTEEM AND GAME PERFORMANCES BASED ON STUDENTS' INITIAL (PRIOR) KNOWLEDGE

\begin{tabular}{|c|c|c|c|c|c|c|c|c|}
\hline \multicolumn{2}{|l|}{} & \multicolumn{2}{|c|}{$\begin{array}{c}\text { Levene's } \\
\text { Test for } \\
\text { Equality of } \\
\text { Variances }\end{array}$} & \multicolumn{5}{|c|}{ t-test for Equality of Means } \\
\hline \multicolumn{2}{|c|}{} & $\boldsymbol{F}$ & Sig. & $t$ & $d f$ & $\begin{array}{l}\text { Sig. (2- } \\
\text { tailed) }\end{array}$ & $\begin{array}{c}\text { Mean } \\
\text { Difference }\end{array}$ & $\begin{array}{c}\text { Std. Error } \\
\text { Difference }\end{array}$ \\
\hline $\begin{array}{c}\text { Self } \\
\text { Esteem }\end{array}$ & $\begin{array}{c}\text { Equal } \\
\text { ariances } \\
\text { assumed }\end{array}$ & .07 & .79 & 2.03 & 28.00 & .052 & 1.15 & .57 \\
\hline $\begin{array}{l}\text { Skill } \\
\text { Play }\end{array}$ & $\begin{array}{c}\text { Equal } \\
\text { ariances } \\
\text { assumed }\end{array}$ & 1.01 & .32 & .63 & 28.00 & .531 & -.19 & .30 \\
\hline
\end{tabular}

Table 4 above depicted the comparison test of self-esteem enhancement and basketball playing skills based on the initial knowledge of students who are divided into two major groups, namely upper and lower classes. The results show that the selfesteem variable obtained $\mathrm{t}$ value $=2.03$ and $\mathrm{p}$ _value $=0,052$ $(0,052>0,05)$. This shows that there is no significant difference between groups of students with low initial knowledge and high initial knowledge both of male and female, which means that self-esteem enhancement is not influenced by students' cognitive skills.

On game performances variable, it is obtained t value = 0.63 and $\mathrm{p} \_$value $=0,531(0,531>0,05)$. This indicates that there is no significant difference between students with low 
initial knowledge and high initial knowledge group both of male and female in improving their game performances, which means that the improvement of game performances is not influenced by students' cognitive skills.

\section{DISCUSSION AND CONCLUSION}

Based on the results, it can be concluded that self-esteem and game performances enhancement using learning of Physical Education in basketball on junior high school is absolutely necessary. The result is positive; students are now learning and improving their self-esteem and basketball skills with a joy and fun. Therefore, teachers have an important role in developing these skills. That is, self-esteem and game performances will be developed when they are introduced in curriculum and used during the lesson. Thus, as what have been shown in this study, self-esteem and game performances can be learned. As a result, students must appropriately learn how to behave and to avoid problems in the future, in the class or in their daily life. After analyzing the results, it can be observed that male students initially have higher levels of selfesteem and game performances than female students, and there are also some students (both male and female) who have higher levels than others.

It is true that some students have acquired these skills in other contexts outside the school. However, the other students do not show the skills because they did not learn it before.

\section{REFERENCES}

[1] S. Coopersmith, The antecendents of self esteem. San francisco: freeman and company, 1967

[2] R.M. Hapsari, "Sumbangan perilaku asertif terhadap harga diri pada remaja," Jurnal Psyche, vol. 5, 2006.

[3] Ismail, "Harga diri dan Aktualisasi diri dengan partisipasi mahasiswa dalam gerakan sosial," Jurnal, vol. 1, no. 1, pp. 12-55, 2005.

[4] R. Srivastava and S. Joshi, "Relationship between self concept and self esteem, in adolescents," International journal of advanced reasearch, vol. 2, issue 2, pp. 36-43, 2014.

[5] M. Ferkany, "The educational importance of self esteem," Journal of philosophy of education, vol. 42, no. 1, 2008.

[6] A. Suherman, Revitalisasi pengajaran dalam pendidikan jasmani. Bandung: CV. Bintang warli artika, 2009.

[7] P. Pearson, "Developing effective questioning inteaching games for understanding," 1st Asia Pacific Sport in Education Conference: Ngunyawaiendi Yerthoappendi Play to Educate, Adelaide, 21 January 2008.

[8] M. Mckey and Judith, Self Esteem: Second edition. California: New Harbinger publication Inc, 1992

[9] P. Dalgas-pelish, "Effects of self esteem intervention program on school age children," Pediatric nursing, vol. 8, pp. 341-349, 2006.

[10] M.S. Trembly, "The realtionship between physical activity, self estem and academic achievement in 12-year-old children," Pediatric exercise science, human kinetic publisher, inc 2000, vol. 12, 2006, pp. 312-323.

[11] J.L. Oslin, S.A. Mitchell and L.L. Griffin, "The game performance assessment instrument (GPAI): development and preliminary validation," Journal of teaching in physical education, vol. 17, pp. 231243), 1998. 